\title{
MODEL PENGAKUAN HAK KONSTITUSIONAL DALAM BERAGAMA (STUDI KOMPARASI MENURUT UUD INDONESIA 1945 DAN KONSTITUSI MALAYSIA 1957)
}

\author{
Rio Armanda Agustian dan Abdul Rasyid Saliman bin Mohd. Arsyad Midin \\ Fakultas Hukum, Universitas Bangka Belitung \\ rioarmanda.agustian@yahoo.com
}

\begin{abstract}
This study aims to describe how the Model of Recognition of Constitutional Rights in Religion (Comparative Study according to the 1945 Constitution and the Malaysian Constitution 1957). Where both countries have the same culture but adhere to different legal systems. The object of the research is the Model of Recognition of Constitutional Rights in Religion and the source of local culture that is thick with traditional Malay traditions which if managed properly will provide welfare for the relations of the two countries. The authenticity of this research is that in recognizing constitutional rights for citizens clearly in religion, it is important as a source of inspiration in the formation of law. The type of research used is normative legal research. The results of this study indicate that in Indonesia, although there is no clear recognition that Islam is a state religion, there is a clear recognition of Islam in both the Third Paragraph and the Fourth Opening of the 1945 Constitution and in Article 29. The 1945 Constitution as a state religion. In Indonesia, in practice the recognition of religious rights can be seen in the making of several laws and regulations such as Hajj Law, Zakat Law, Sharia Banking Law, Religious Courts Law, Marriage Law, Qanun in Aceh and Sharia Regulations in several Provinces in Indonesia. In the Malaysian constitution, the principle of protecting constitutional rights in religion occupies a very important, universal position and at the same time asserts that Malaysia is characterized as a state of law, but in the practice of daily life there are still many things to consider. adjusted to the rule of law. In work or work there are still many violations of religious freedom, the issue of prohibiting employers and labor agents on the freedom of Muslim domestic workers to fast, pray and avoid pigs and dogs in connection with their religious beliefs is abuse and violation of religious freedom as protected In the Universal Declaration of Rights Humanity. Although in the Malaysian Constitution it is clear that Islam is the official religion of the state, but the practice of prohibition and pressure to carry out religious duties in the workplace remains a very serious obstacle.
\end{abstract}

Keywords: Model of Recognition; Constitutional Rights in Religion; Republic of Indonesia 1945 Constitution; Malaysian Constitution 1957

\begin{abstract}
Abstrak
Penelitian ini bertujuan untuk mendeskripsikan bagaimana Model Pengakuan Hak-Hak Konstitusional dalam Agama (Studi Banding menurut UUD 1945 dan Undang-Undang Dasar Malaysia 1957). Di mana kedua negara memiliki budaya yang sama tetapi mematuhi sistem hukum yang berbeda. Objek penelitian adalah Model Pengakuan Hak Konstitusional dalam Agama dan sumber budaya lokal yang kental dengan tradisi tradisional Melayu yang jika dikelola dengan baik akan memberikan kesejahteraan bagi hubungan kedua negara. Keaslian penelitian ini adalah bahwa
\end{abstract}


dalam mengakui hak-hak konstitusional untuk warga negara secara jelas dalam agama, penting sebagai sumber inspirasi dalam pembentukan hukum. Tipe penelitian yang digunakan adalah penelitian hukum normatif . Hasil penelitian ini menunjukkan bahwa Di Indonesia, meskipun tidak ada pengakuan yang jelas bahwa Islam adalah agama negara, ada pengakuan yang jelas tentang Islam baik dalam Paragraf Ketiga dan Keempat Pembukaan Undang-Undang Dasar 1945 serta dalam Pasal 29. Badan UUD 1945 sebagai agama negara. Di Indonesia, dalam praktik pengakuan hak-hak agama dapat dilihat dalam pembuatan beberapa undang-undang dan peraturan seperti Hukum Haji, Hukum Zakat, Hukum Perbankan Syariah, Hukum Pengadilan Agama, Hukum Perkawinan, Qanun di Aceh dan Peraturan Syariah di beberapa Provinsi di Indonesia. Dalam konstitusi Malaysia, prinsip perlindungan hak-hak konstitusional dalam agama menempati posisi yang sangat penting, universal dan pada saat yang sama menegaskan Malaysia dicirikan sebagai negara hukum, tetapi dalam praktik kehidupan sehari-hari masih banyak hal yang perlu diperhatikan. disesuaikan dengan aturan hukum. Dalam pekerjaan atau pekerjaan masih ada banyak pelanggaran kebebasan beragama, masalah larangan majikan dan agen tenaga kerja pada kebebasan pekerja rumah tangga Muslim untuk berpuasa, berdoa dan menghindari babi dan anjing sehubungan dengan keyakinan agama mereka adalah pelecehan dan pelanggaran agama kebebasan sebagai dilindungi Dalam Deklarasi Universal Hak Asasi Manusia. Meskipun dalam Konstitusi Malaysia jelas bahwa Islam adalah agama resmi negara, tetapi praktik larangan dan tekanan untuk melakukan tugas-tugas keagamaan di tempat kerja tetap menjadi hambatan yang sangat serius.

Kata kunci: Model Pengakuan; Hak Konstitusi dalam Beragama; UUD RI 1945; Konstitusi; Malaysia 1957

\section{A. Pendahuluan}

\section{Latar Belakang Masalah}

Terdapat pemahaman umum bahwa pemerintahan suatu negara memiliki kewajiban untuk memberikan perlindungan bagi warganya. Upaya perlindungan tersebut akan menjadi rumit apabila warga negara belum memahami hak dan kewajibannya sebagai individu, kelompok agama, dan dalam konteks berbangsa dan bernegara. Meskipun hal tersebut sudah di atur di dalam konstitusi negara, namun pada kenyataannya masih banyak terdapat hambatan-hambatan sebagai akibat terus dan berkembangnya paradigma baru tentang ideologi, peran dan fungsi agama itu sendiri. Maksud dari pemberian perlindungan tersebut adalah perlindungan terhadap hak-hak dasar dari semua kelompok agama baik mayoritas maupun minoritas dan bersifat nondiskriminasi dengan menyesuaikan terhadap perkembangan agama tersebut.
Islam dalam menjalankan sebuah kekuasaan sangat berkaitan dengan hak asasi manusia, selain melindungi hak hidup manusia, Islam juga melindungi harta, melarang melakukan paksaan atas dasar sentimen agama dan adanya larangan yang merendahkan martabat manusia. ${ }^{1}$

Pada saat ini, ada dua perubahan besar yang mendorong, munculnya pandangan liberal modern tentang dasar hak, pertama, lumpuhnya sejarah dan peseden sebagai landasan pembenar politik, dan kedua, semakin kecilnya kemungkinan menggunakan agama sebagai landasan pembenar prinsipprinsip politik. $^{2}$

Namun di Indonesia, masalah perlindungan dan pengakuan hak dalam

\footnotetext{
${ }^{1}$ Fokky Fuad Wasitaatmadja, 2017, Filsafat Hukum, Akar Religiositas Hukum, Jakarta: Prenadamedia Group, hlm. 175.

${ }^{2}$ Ian Shapiro, 2006, Evolusi Hak dalam Teori Liberal, Jakarta: Freedom Institute dan Yayasan Obor Indonesia. hlm. 299.
} 
beragama merupakan hak konstitusional warga negara yang di jamin dalam UUD 1945. Perlindungan warga negara Indonesia seperti yang tertuang dalam Pembukaan UUD 1945 Alinea IV dan dalam Pasal 29 UUD 1945 merupakan perlindungan yang diberikan negara kepada seseorang warga negara Indonesia ataupun lembaga-lembaga negara dalam melaksanakan ajaran agamanya. Di Indonesia pengakuan hak konstitusi dalam beragama sudah diatur secara jelas, meskipun Indonesia tidak mengakui agama Islam sebagai agama resmi negara.

Di Malaysia, masalah perlindungan hak konstitusi dalam beragama juga sudah diatur dalam Konsitusi Malaysia 1957. Malaysia mengakui agama Islam sebagai agama resmi negara. Oleh karena itu, sangat menarik bila kita mengkaji dan menelaah model pengakuan hak konstitusional beragama tersebut dalam pelaksanaannya di kedua negara.

Memberikan perlindungan hak bagi warga negara dalam menjalankan agama berada di tangan pemerintah meskipun sudah diatur dalam konstitusi, namun tanpa ada pemahaman dari warga negara masing-masing negara dalam pelaksanaan fungsi perlindungan akan sangat sulit dilakukan dan warga negara juga harus tahu hak dan kewajibannya. ${ }^{3}$

Kebebasan beragama di negara Indonesia mengacu pada UUD 1945 pasal 29 ayat 2 . Pasal ini menyatakan bahwa setiap warga diberi kemerdekaan atau kebebasan untuk memeluk agamanya masing-masing dan beribadat menurut agama dan kepercayaannya. Pasal 28 ayat 1 UUD 1945 perubahan kedua mengakui adanya hak setiap warga negara atas kebebasan beragama atau kepercayaan, demikian juga Pasal 28 ayat 1 UUD 1945 perubahan kedua, menjelaskan hak beragama dan berkepercayaan adalah Hak Asasi Manusia (HAM) yang tidak bisa

3 Neil Maccormick, 1986, Legal Right and Social Democracy, Oxford: Clarendon Press, hlm.15. dikurangi dan dibatasi dalam kondisi apapun. Bahkan Pasal 28 ayat 4 UUD 1945 perubahan kedua, mempertegas kewajiban negara terutama pemerintah untuk melindungi, memajukan, menegakkan dan memenuhi HAM. Kewajiban negara melindungi dan memenuhi hak atas kebebasan beragama dan kepercayaan mengandung pengertian, bahwa negara tidak mempunyai wewenang mencampuri urusan agama dan kepercayaan setiap warga negaranya. Sebaliknya, negara harus memberikan perlindungan terhadap setiap warga negaranya untuk melaksanakan ibadah keagamaan atau kepercayaan.

Perkara 11 tentang Kebebasan Beragama dalam Undang-undang Perlembagaan Persekutuan Malaysia menyatakan bahwa:

(1) Tiap-tiap orang adalah berhak menganuti dan mengamalkan agamanya dan, tertakluk kepada pasal (4), mengembangkan.

(2) Tiada seorang pun boleh dipaksa membayar apa-apa cukai yang hasilnya diuntukkan khas kesemuanya atau sebahagiannya bagi maksud sesuatu agama selain agamanya sendiri.

(3) Tiap-tiapkumpulan agama berhak

(a) Menguruskan hal ihwal agamanya sendiri;

(b)Menubuh dan menyelenggara yayasan untuk tujuan agama masing-masing dan khairat, memperolehi dan

(c)Mempunyai harta serta memegang dan mentadbirkannya mengikut Undangundang.

(4) Undang-undang Negeri dan mengenai Wilayah-wilayah Persekutuan Kuala Lumpur dan Labuan, Undang-undang Persekutuan boleh mengawal atau menyekat pengembangan apa-apa iktikad atau kepercayaan agama antara orang-orang yang menganuti agama Islam.

(5) Perkara ini tidaklah membenarkan apaapa perbuatan yang berlawanan dengan mana-manaUndang-undang yang 
berhubungan dengan ketenteraman awam, kesihatan awam atau prinsip moral. ${ }^{4}$

Perkara 11 tentang kebebasan beragama ini bermakna bebas dalam menganut, mengamal dan mengembangkan agama. Perkara 11 (1) menjelaskan bahwa setiap orang berhak dalam menganut agama yang diinginkan nya serta mengamalkan dan mengikuti kepercayaan agama tersebut. ${ }^{5}$

Perkara 11 (2) bermaksud di dalam menganut satu agama tertentu, seseorang tidak perlu membayar biaya apapun dan tidak terikat pada jenis ketentuan manapun, cukup berpedoman pada agama yang dianutinya saja. Perkara 11 (3) menyebutkan bahwa setiap persatuan agama berhak untuk melakukan apa saja yang berkaitan dengan agamanya sendiri. Misalnya, sebagai seorang yang beragama Islam, ingin membangun masjid, mengumpulkan sumbangan, dan mengadakan majlistaklim tanpa ada halangan asalkan saling menjaga dan menghormati antara sesama agama lainya. Perkara 11 (4) yang menyatakan bahwa "apa-apa perkembangan agama yang menggangu agama Islam yang boleh menyebabkan seseorang itu keluar dari agama Islam". ${ }^{6}$ Yang terakhira dalah perkara 11 (5) yang bermakna bahwa tiap-tiap agama tidak boleh melakukan tindak kekerasan dan intimidasi terhadap agama lain, harus mematuhi setiap perundang-undangan yang telah ditetapkan. ${ }^{7}$

Pemberian perlindungan dan pengakuan harus di lihat secara cermat dan tepat mengingat hambatan-hambatan yang dihadapi di lapangan karena hak beragama adalah hak

\footnotetext{
${ }^{4}$ Undang-undang Malaysia, Perlembagaan

Persekutuan, Perkara 11 ,hlm. 12

5 Mohamed Azam Mohamed Adil, Liberalisme dan Pluralisme agama impak kepada perlembagaan dan sistem perundagan Islam di Malaysia, (Selangor: Rekacetak, 2015), hlm. 14.

${ }^{6}$ Ibid., hlm 15

${ }^{7}$ Ibid., hlm 16
}

yang di jamin secara universal menurut hukum internasional yang berlaku. ${ }^{8}$

Berkaitan dengan hal tersebut di atas, pada penelitian ini penulis tertarik untuk membahas model pengakuan hak konstitusional dalam beragama, studi komparasi menurut UUD Indonesia 1945 dan Konstitusi Malaysia 1957.

\section{Perumusan Masalah}

Permasalahan yang ingin dikemukakan adalah sebagai berikut :

a. Bagaimanakah model pengakuan hak konstitusional dalam beragama di Indonesia dan Malaysia?.

b. Apakah perlindungan hak konstitusional dalam beragama menurut UUD Indonesia 1945 dan Konstitusi Malaysia 1957 sudah dilaksanakan sebagaimana mestinya?

\section{Tujuan Penelitian}

Tujuan yang ingin dicapai melalui penelitian ini adalah untuk:

a. Mengetahui, mendalami dan menganalisa model pengakuan hak konstitusional dalam beragama di Indonesia dan Malaysia.

b. Mengetahui, mendalami dan menganalisa Indonesia dan Malaysia sudah melindungi hak konstitusional dalam beragama dan telah memperoleh jaminan dalam pelaksanaan menurut UUD Indonesia 1945 dan Konstitusi Malaysia 1957.

\section{Kerangka Teoretis dan Konseptual}

Penelitian ini mengacu kepada kerangka teori tentang campur tangan negara dalam bidang agama, khususnya masalah perlindungan hak beragama dalam konsep negara hukum Indonesia dan Malaysia. Konsep pengakuan hak beragama bagi rakyat merupakan konsep universal, dalam arti di anut dan diterapkan oleh setiap negara yang

\footnotetext{
${ }^{8}$ Austin Sarat dan Thomas R. Kearns, 2000, Legal Rights, Michigan: The University of Michigam Press.hlm.206.
} 
mengedepankan diri sebagai negara hukum, namun masing-masing negara mempunyai cara dan mekanismenya sendiri tentang bagaimana mewujudkan pengakuan tersebut, dan juga sampai seberapa jauh perlindungan hak itu diberikan.

Memperhatikan masalah perlindungan hak bagi rakyat dalam menjalankan ajaran agama yang merupakan cita negara (staatsidee), maka di sini akan dikemukakan beberapa uraian teori yang mendukung terhadap pencapaian cita negara sekaligus pula uraian teori ini untuk membantu dalam mengkaji dan menganalisis permasalahan yang sedang di teliti. Untuk dapat memberikan jawaban terhadap rumusan masalah penelitian ini, digunakan konsep "Negara Hukum" sebagai teori utama (grand theory), kemudian diperkuat dengan teori konstitusi, serta teori perundang-undangan dan teori tentang hak sebagai teori madya (middle range theory). Selanjutnya dipergunakan teori dan konsep perlindungan hak dalam beragama sebagai teori aplikasi (applied theory). Berikut ini diuraikan ketiga teori di maksud.

Penggunaan teori dan konsep negara hukum sebagai teori utama (grand theory) berdasarkan pada pemahaman bahwa salah satu tujuan yang tersirat dalam UUD Republik Indonesia 1945 dan Konstitusi Malaysia 1957 adalah semua orang diakui sama di depan hukum dan berhak mendapat perlindungan hukum dan pengakuan yang sama. Masalah perlindungan hukum dan pengakuan hak ini tidak boleh ada diskriminasi baik terhadap warga negara dengan dasar agama, ras, keturunan atau tempat lahir dalam hukum apa saja yang berkaitan dengan kekayaan, perdagangan, bisnis, profesi, lapangan kerja atau pekerjaan. Suatu hal yang mustahil apabila dalam membangun hubungan antar negara dan martabat kemanusiaan mengabaikan perlindungan hukum dan pengakuan hak, keberadaan dan fungsi hukum dalam arti sebenarnya.
Sedangkan penggunaan teori konstitusi, teori perundang-undangan dan teori tentang hak dijadikan sebagai teori madya (middle range theory), karena untuk mengungkapkan tata urutan, alur kedudukan dan kekuatan mengikat materi muatannya.

Begitu pula halnya dengan penggunaan teori dan konsep perlindungan hukum dan pengakuan hak sebagai teori aplikasi (applied theory), karena pada konsep pengakuan hak bertujuan untuk mencegah terjadinya konflik dan untuk menyelesaikan konflik di antara warga negara dalam melaksanakan ajaran agamanya.

Seperti kita ketahui, konsepsi negara hukum liberal Immanuel Kant berkembang menjadi negara hukum formal, hal ini dapat dipetik dari pendapat F.J. Stahl tentang negara hukum formal, karena lebih menekankan pada suatu pemerintahan yang berdasarkan undang-undang yang ditandai oleh empat unsur pokok yaitu $:^{9}$

a. Mengakui dan melindungi hak-hak asasi manusia.

b. Untuk melindungi hak asasi tersebut maka penyelenggaraan negara harus berdasarkan pada teori trias politica.

c. Dalam menjalankan tugasnya, pemerintahan berdasar atas undangundang (wetmatig bestuur).

d. Apabila dalam menjalankan tugasnya berdasarkan undang-undang pemerintah masih melanggar hak asasi (campur tangan pemerintah dalam kehidupan pribadi seseorang), maka ada pengadilan administrasi yang akan menyelesaikannya. Stahl hanya mengutamakan aspek formalnya saja, sehingga hak asasi dan kebebasan individu terlindungi secara formal saja. Pembatasan yang ketat dengan undangundang telah mempersempit ruang gerak

\footnotetext{
${ }^{9}$ Muhammad Tahir Azhary, 2004, Negara Hukum, Suatu Studi tentang Prinsip-Prinsipnya Dilihat dari Segi Hukum Islam, Implementasinya pada Periode Negara Madinah dan Masa Kini, Jakarta: Prenada Media, hlm.46.
} 
pemerintah dalam penyelenggaraan negara, sehingga pemerintah menjadi kaku dan tidak dapat mengelola negara untuk mencapai masyarakat yang bebas dan makmur bagi setiap individu.

Karena konsep rechtsstaat di Eropa Kontinental sejak semula didasarkan pada filsafat liberal yang individualistik, maka ciri individualistik itu sangat menonjol dalam pemikiran negara hukum menurut konsep Eropa Kontinental itu.

Adapun ciri-ciri negara hukum Eropa Kontinental (rechtsstaat) menurut F.J. Stahl adalah sebagai berikut: ${ }^{10}$

a. Mengakui dan melindungi hak-hak asasi manusia;

b. Untuk melindungi hak asasi tersebut maka penyelenggaraan negara harus berdasarkan trias politica;

c. Dalam menjalankan tugasnya, pemerintah berdasarkan atas undang-undang (wetmatig bestuur);

d. Apabila dalam menjalankan tugasnya berdasarkan undang-undang pemerintah masih melanggar hak asasi (campur tangan pemerintah dalam kehidupan pribadi seseorang), maka ada pengadilan administrasi yang akan menyeleasaikannya.

Di negara-negara Anglo-Saxon berkembang pula konsep negara hukum yang semula dipelopori oleh Albert Venn Dicey (salah seorang pemikir Inggris yang termasyur) dengan sebutan rule of law, konsep ini menekankan kepada 3 unsur utama rule of law, yaitu: ${ }^{11}$

a. Supremasi Hukum (Supremacy of Law).

b. Persamaan kedudukan di depan Hukum (Equality before the Law).

${ }^{11}$ Albert Van Dicey, 1952, Introduction to the Study of the Law of the Constitution, London: McMillan and Co., Limited St.Martin's Street, Terjemahan 2007 oleh Nurhadi, Bandung: Nusamedia.Internasional, Vol. 3, No. 3, Jakarta: LPHI-FH-Universitas Indonesia, hlm.251. c. Konstitusi bersumber kepada Hak-hak Individu (Constitution based on Individual Rights).

Perbedaan yang menonjol antara konsep rechsstaat dan rule of law ialah pada konsep yang pertama bahwa peradilan administrasi negara merupakan sarana yang sangat penting dan sekaligus pula ciri yang menonjol pada rechsstaat itu sendiri. Sebaliknya kepercayaan masyarakat yang demikian besar pada peradilan umum membentuk ciri yang menonjol pada konsep rule of law, yang mana ciri tersebut ialah ditegakkannya hukum yang adil dan tepat (just law). Karena seseorang yang mempunyai kedudukan yang sama dihadapan hukum, maka ordinary court dianggap cukup untuk mengadili semua perkara termasuk perbuatan melanggar hukum oleh pemerintah. ${ }^{12}$

Dalam perspektif negara hukum, supremasi hukum dalam rule of law mengatakan bahwa tak seorangpun yang dapat di hukum atau secara hukum dapat dibuat menderita tubuh atau harta bendanya kecuali atas pelanggaran hukum tertentu yang tertuang dalam tata cara hukum biasa dihadapan pengadilan umum negara. Menurut pengertian ini, rule of law bertentangan dengan sistem pemerintahan manapun yang didasarkan pada pelaksanaan kekuasaan menindas yang begitu luas, sewenangwenang, atau tanpa batas oleh orang-orang yang berkuasa. ${ }^{13}$

Unsur ketiga dari rule of law adalah konstitusi dijiwai oleh rule of law dengan alasan bahwa prinsip-prinsip umum konstitusi (misalnya, terkait dengan hak akan kebebasan pribadi, atau hak untuk mengadakan rapat umum) yang merupakan hasil dari keputusan yudisial yang menentukan hak-hak individu pada kasus-kasus tertentu yang di bawa ke muka pengadilan, sedangkan menurut banyak

12 Deddy Ismatullah,Gagasan Pemerintahan Modern Dalam Konstitusi Madinah, Ctk Pertama, Pustaka Attadbir, Bandung, 2006.Hlm.40

${ }^{13}$ Ibid, hlm.254. 
konstitusi asing jaminan (sebagaimana adanya) yang diberikan pada hak-hak individu berasal, atau kelihatan berasal, dari prinsipprinsip umum konstitusi. ${ }^{14}$

Penggunaan kerangka berpikir dalam konteks negara hukum Indonesia, didasarkan atas beberapa pertimbangan bahwa UUD Indonesia 1945 terdapat norma hukum yang merupakan kaidah dasar yang menjadi dasar konsep negara hukum Indonesia. Begitupun penggunaan kerangka berpikir negara hukum Malaysia, didasarkan atas beberapa pertimbangan bahwa naskah Konstitusi Malaysia 1957 (telah diubah tahun 1964, dan diubah lagi tahun 1971), setidaknya terdapat beberapa norma hukum ${ }^{15}$ yang merupakan kaidah-kaidah fundamental yang telah mendasari konsep negara hukum Malaysia.

Dengan demikian kerangka pemikiran teoretis dan konseptual sebagaimana di maksud, mempunyai relevansi yang kuat dengan fakta adanya berbagai hambatan perlindungan hukum dan pengakuan hak konstitusi oleh Pemerintah Indonesia, khususnya terhadap hak beragama waga negaranya, dan Pemerintah Malaysia terhadap warga negara Malaysia dan warga negara asing khususnya buruh migran Indonesia yang ada di sana, antara lain menjadi pokok permasalahan yang di teliti dalam penelitian ini.

\section{B. Metode Penelitian}

\section{Objek dan Tempat Penelitian}

Objek penelitian adalah model pengakuan hak konstitusi dalam beragama, sedangkan subjek penelitian adalah hak dalam beragama menurut UUD RI 1945 dan Kostitusi Malaysia 1957 dengan tempat penelitian dilaksanakan di Indonesia dan Malaysia. Indonesia telah mengakui secara jelas hak

\footnotetext{
${ }^{14}$ Ibid,.hlm. 260.

${ }^{15}$ Munir Fuady, 2014, Teori-Teori Besar dalam

Hukum, Jakarta: Prenadamedia Group, hlm.148-149.
}

dalam beragama meskipun tidak menyebutkan agama Islam sebagai agama resmi negara. Malaysia merupakan negara dengan sistem Monarchi Konstitusionil di Asia Tenggara yang memiliki kesamaan budaya dengan Indonesia, namun latar belakang sejarah dan sistem hukum yang diterapkan berbeda. Malaysia menerapkan sistem hukumnya berdasarkan sistem English Common Law dan telah megakui secara resmi Islam sebagai agama negara. ${ }^{16}$

\section{Tipe dan Pendekatan Penelitian}

Sebagai konsekuensi pemilihan topik permasalahan yang akan dikaji dalam penelitian yang objeknya perlindungan hakhak dalam beragama menurut konstitusi yang dibatasi pada peraturan perundang-undangan di Indonesia dan Malaysia, maka tipe penelitian yang digunakan adalah penelitian hukum normatif, yakni penelitian yang difokuskan untuk mengkaji penerapan kaidahkaidah atau norma-norma dalam hukum positif. ${ }^{17}$ Dalam hubungan ini, digunakan logika induktif. Logika induktif digunakan untuk menarik kesimpulan dari kasus yang bersifat individual menjadi hal yang bersifat umum. ${ }^{18}$ Dalam penelitian ini juga secara proporsional menggunakan penelitian sosiolegal ${ }^{19}$ dan dalam hal ini, digunakan

16 Ade Maman Suherman, 2004, Pengantar Perbandingan Sistem Hukum,Jakarta: PT Raja Grafindo Persada,hlm.314.

17 I Made Pasek Diantha, 2016, Metodologi Penelitian Hukum Normatif, Jakarta: Prenadamedia Group, hlm.152. Untuk hal yang sama lihat juga Lili Rasjidi dan Liza Sonia Rasjidi, 2005, Pengantar Metode Penelitian dan Penulisan Karya Ilmiah Hukum, Bandung: FH-UNPAD, hlm.10

${ }^{18}$ Johnny Ibrahim, 2006,Teori dan Metodologi

Penelitian Hukum Normatif, Malang: Bayumedia Publishing, hlm.242. Untuk hal yang sama lihat juga Jonaedi Efendi dan Johnny Ibrahim, 2018, Metode

Penelitian Hukum, Normatif dan Empiris, Jakarta: Prenadamedia Group,hlm.153.

19 Adriaan Bedner, 2001, Administrative Courts in Indonesia, A Socio-Legal Study, Kluwer Law International, The Hague-Netherland, hlm.8-9, menjelaskan, "It will be clear that the different perspective from which I have studied the 
logika deduktif guna menarik kesimpulan dari hal yang bersifat umum ke hal yang bersifat individual. ${ }^{20}$

Dalam kaitannya dengan penelitian normatif disini digunakan beberapa pendekatan, yaitu pendekatan perundangundangan (statute approach). Pendekatan tersebut melakukan pengkajian peraturan perundang-undangan yang berhubungan dengan tema sentral penelitian. Selain itu juga digunakan pendekatan perbandingan (comparative approach), dan pendekatan sejarah (historical approach) yang diperlukan guna memperjelas analisis ilmiah yang diperlukan dalam penelitian normatif.

\section{Prosedur Pengumpulan Bahan Penelitian}

Untuk memperoleh bahan penelitian dilakukan dengan prosedur pengumpulan melalui dua cara, yakni: Pertama, studi kepustakaan, studi kepustakaan tidak saja terhadap bahan-bahan perundangan, penulis juga mencari bahan pada buku-buku, jurnaljurnal, makalah-makalah, laporan-laporan, hasil penelitian, bahan-bahan yang diperoleh dari internet dan keputusan-keputusan pengadilan terdahulu yang berhubungan dengan masalah perlindungan hak beragama di Indonesia dan Malaysia serta menggali permasalahan-permasalahan yang timbul dalam penerapan Undang-Undang dan Akta yang memuat perlindungan hak dalam menjalankan agama di Indonesia dan

administrative courts require different research methods. As noted above, the problema for legal scholar who embarks on a conventional positivist legal analysis. ......and I had together my material from various sources. I obstained information on cases via observation, press report and interviews".

${ }^{20}$ Anwarul Yaqin, 2007, Legal Research and Writing, Selangor DE, Lexis Nexis Malaysia Sdn.Bhd, hlm.10, menjelaskan, in the doctrinal research " justice, fairness, protection of rights, freedom and liberty are often used by the researcher as the criterion to evaluate the relevance or effectiveness of laws, concepts or legal institutions. The underlying aim of such research is to gain and present new knowledge and ideas or to suggest change and reform".
Malaysia, dan; Kedua, wawancara, dimana bahan hukum diperoleh dengan mewawancarai warga negara, kelompok agama di Indonesia maupun di Malaysia.

Jenis bahan yang digunakan dalam penelitian ini, yakni; jenis bahan primer dan bahan sekunder. Jenis bahan primer, yakni jenis bahan yang di dapat berdasarkan hasil di lapangan dengan wawancara dan sifatnya sebagai pelengkap (komplementer), sedangkan jenis bahan sekunder merupakan jenis bahan yang di dapat bukan dari lapangan dan di dapat dalam bentuk tiga bahan hukum, yakni;

Bahan hukum yang dikaji meliputi beberapa hal berikut :

a. Bahan hukum primer, yaitu bahan-bahan hukum yang formal, yakni UUD RI 1945 dan Konstitusi Malaysia 1957 dan peraturan perundang-undangan yang berhubungan dengan perlindungan hukum dan pengakuan hak-hak dalam beragama.

b. Bahan hukum sekunder, yaitu bahan hukum yang terdiri atas buku-buku teks (textbooks) yang ditulis para ahli hukum yang berpengaruh, jurnal-jurnal hukum, pendapat para sarjana, kasus-kasus hukum, yurisprudensi, dan hasil-hasil simposium mutakhir yang berkaitan dengan topik penelitian.

c. Bahan-bahan tersier, yaitu bahan yang memberikan petunjuk maupun penjelasan terhadap bahan hukum primer dan sekunder, seperti; kamus, ensiklopedi dan lain-lain.

Setelah prosedur pengumpulan bahan hukum primer, bahan hukum sekunder, dan bahan-bahan tersier dilakukan, kemudian bahan hukum tersebut diinventarisasi dan diklasifikasi dengan menyesuaikan dengan masalah yang dibahas. Bahan hukum yang berhubungan dengan masalah yang dibahas dipaparkan, disistematisasi, kemudian dianalisis untuk menginterpretasikan hukum yang berlaku. 


\section{Pengolahan dan Analisis Bahan Penelitian}

Adapun bahan-bahan hukum yang telah diperoleh dalam penelitian kepustakaan, aturan perundang-undangan, dan artikel dimaksud penulis uraikan dan hubungkan sedemikian rupa, sehingga disajikan dalam penulisan yang lebih sistematis untuk menjawab isu hukum yang telah dirumuskan dalam rumusan masalah. Bahwa cara pengolahan bahan hukum dilakukan secara induktif yakni menarik kesimpulan dari suatu permasalahan yang bersifat konkrit yang dihadapi terhadap permasalahan yang bersifat umum. Selanjutnya bahan hukum yang ada dianalisis untuk melihat bentuk perlindungan hukum dan model pengakuan terhadap hakhak warga negara di Indonesia dan Malaysia dalam peraturan perundang-undangannya sehingga dapat membantu sebagai dasar acuan dan pertimbangan hukum yang berguna untuk pelaksanaan dalam memberi pengakuan hak dalam beragama di Indonesia dan Malaysia secara tepat. ${ }^{21}$

\section{Hasil dan Pembahasan}

\section{Model Pengakuan Hak Konstitusional dalam Beragama menurut UUD 1945.}

Di Indonesia, meskipun tidak ada pengakuan secara tegas bahwa Islam adalah agama negara, tetapi ada pengakuan secara prinsipil agama Islam baik di dalam Konstitusi Indonesia 1945 Alinea Ketiga yang menyatakan "atas berkat Rahmat Allah SWT" sudah cukup menyatakan bahwa kemerdekaan Indonesia merupakan anugerah dari Allah SWT dan Islam diakui sebagai agama negara.

Sedangkan di dalam Alinea Keempat Pembukaan UUD 1945 yang berbunyi “ Kemudian daripada itu untuk membentuk suatu Pemerintah Negara Indonesia yang melindungi segenap bangsa Indonesia dan seluruh tumpah darah Indonesia dan untuk memajukan kesejahteraan umum, mencerdaskan kehidupan bangsa, dan ikut melaksanakan ketertiban dunia yang berdasarkan kemerdekaan, perdamaian abadi dan keadilan sosial, maka disusunlah Kemerdekaan kebangsaan Indonesia itu dalam suatu Undang-Undang Dasar Negara Indonesia yang terbentuk dalam suatu susunan Negara Republik Indonesia yang berkedaulatan rakyat dengan berdasarkan kepada Ketuhanan Yang Maha Esa, Kemanusiaan yang adil dan beradab, Persatuan Indonesia, dan Kerakyatan yang dipimpin oleh hikmat kebijaksanaan dalam permusyawaratan/perwakilan, serta dengan mewujudkan suatu Keadilan sosial bagi seluruh rakyat Indonesia". Di sini asas dari pelaksanaan kehidupan bangsa Indonesia adalah asas Ketuhanan YME dalam Islam sebagai prinsip pengakuan fundamental dan merupakan filosofis transendental bagi berlakunya tata kehidupan bagi bangsa Indonesia.

Di dalam Pasal 29 Batang Tubuh UUD 1945 merupakan metayuris dari berlakunya sebagai sumber inspirasi agama Islam dalam pembuatan peraturan perundang-undangan. Di Indonesia, dalam praktik pengakuan hak konstitusional warga negara dalam beragama dapat di temui dalam pembuatan beberapa peraturan perundang-undangan seperti UU Haji, UU Zakat, UU Perbankan Syariah, UU Perkawinan, UU Peradilan Agama, RUU Pesantren, dan berlakunya Qanun-Qanun di Aceh dan Perda-Perda Syariah yang berlaku di beberapa Provinsi dan Kabupaten/Kota di Indonesia.

\section{Model Pengakuan Hak Konstitusional dalam Beragama menurut Konstitusi 1957.}

Malaysia adalah negara hokum rule of law yang sistemnya tertakluk (tunduk) kepada Perlembagaan Persekutuan (Konstitusi Federal) yang merupakan hukum tertinggi negara, berarti di bawah Perkara 4, tidak ada hukum yang boleh mengatasi Perlembagaan

${ }^{21}$ I Made Pasek Diantha, Op.Cit, hlm.152. 
Persekutuan, dan setiap rakyat adalah sama di sisi hukum dan tunduk kepada rule of law. ${ }^{22}$

$$
\text { Ciri-ciri dasar Perlembagaan }
$$

Persekutuan (Konstitusi) Malaysia, sebagai berikut:

a. Malaysia adalah negara Federasi;

b. Malaysia sebagai negara Monarki dengan sistem Parlementer;

c. Islam sebagai agama resmi Federasi;

d. Perlembagaan Persekutuan sebagai hukum tertinggi, dan berkedaulatan hukum;

e. Badan Eksekutif;

f. Adanya kebebasan kehakiman; dan

g. Menjamin adanya tradisi seperti hak istimewa suatu kaum, bahasa kebangsaan dan kerakyatan.

Menurut Johan S. Sabarudin, Konstitusi modern Malaysia berakar dari sistem Inggris, hal ini dapat dilihat dari pengaruh Inggris yang dominan dari komposisi keanggotaan Komisi Konstitusi yang merancang Konstitusi Federal. Seperti halnya negara-negara Asia yang lain, Konstitusi Amerika juga memberi pengaruh dalam praktik konstitusi di Malaysia. Di samping itu terdapat pengaruh Islam dalam Konsitusi Malaysia. Dengan demikian, prinsip-prinsip dan tujuan-tujuan antara model konstitusi Barat dan model konstitusi Islam membuat Konstitusi Malaysia bertambah atraktif dan menjadi sumber yang dapat diterima, yang merupakan campuran pengalaman-pengalaman asing dengan pengalaman-pengalaman lokal sehingga mempengaruhi rule of law dalam konsep negara hukum Malaysia.

Sedangkan unsur negara hukum Malaysia menurut Johan S.Sabarudin sebagai berikut: ${ }^{23}$

\footnotetext{
${ }^{22}$ Kamal Halili Hassan, 1990, Penulis dan UndangUndang, Selangor DE: Dewan Bahasa dan Pustaka, hlm. 10 .

23 Johan S. Sabarudin, 2006, Constitutionalism-Concept and Application in the Federal and State Goverments of Malaysia, Jurnal of Malaysian and Comparative Law, Vol.3, Kuala Lumpur: Faculty of Law, University of Malaya, hlm.44.
}

a. Jaminan kebebasan bagi setiap orang (guaranteeing liberty of the person).

b. Perlindungan terhadap hukum pidana yang lalu dan tuntutan yang berulangulang (protection against retrospective criminal laws and repeated trials).

c. Persamaan (equality).

Di samping pengaruh agama Islam, Malaysia adalah salah satu bekas jajahan Inggris, sehingga tradisi rule of law juga ikut mempengaruhi konsep negara hukum Malaysia. ${ }^{24}$

Unsur utama negara hukum Malaysia adalah sebagai berikut:

a. Bersumber pada agama Islam.

b. Prinsip musyawarah

c. Perlindungan hukum serta hak-hak kewarganegaraan lainnya (citizenship).

d. Prinsip keadilan dan persamaan (equality before the law)

e. Kebebasan dasar (fundamental liberties)

f. Badan kehakiman yang bebas dan tidak memihak.

Tentang prinsip perlindungan hukum dalam pasal 8 Konstitusi Malaysia 1957 dengan tegas menyatakan bahwa Malaysia memberikan perlindungan hukum terhadap semua orang yang di akui sama di depan hukum dan berhak mendapat perlindungan hukum yang sama.

Pasal 8 dari Konstitusi Malaysia yang menyatakan bahwa "semua orang adalah sama dihadapan hukum dan diberikan hak perlindungan hukum yang sama" dan penggunaan terminologi "orang" sebagai hal yang bertentangan terhadap "warga negara" membuat hal tersebut sangat jelas bahwa garansi hak-hak ini diberikan juga untuk semua orang-orang termasuk pekerja migran, baik yang berdokumen maupun yang tidak berdokumen. $^{25}$

\footnotetext{
${ }^{24}$ Muhammad Tahir Azhary, Loc.Cit, hlm.217.

25 Charles Hector, 2006, Migrants and Rights in Malaysia more Important than Rights is the Access to
} 
Menurut Pasal 3 Ayat (1) Konstitusi Malaysia, menyatakan :

"Islam is the religion of the Federation, but other religions may be practised in peace and harmony in any part of the Federation".

(Islam adalah agama Persekutuan, tetapi agama-agama lain yang dipraktikkan dalam cara damai dan harmoni adalah bagian dari Persekutuan).

Pasal tersebut dengan tegas menyatakan bahwa Islam adalah agama negara Federasi. Ketentuan itu menunjukkan bahwa Federasi Malaysia adalah suatu negara yang mencantumkan dengan resmi Islam sebagai agama negara. Konsekuensi logis dari ketentuan itu, adanya hubungan antara Federasi Malaysia sebagai negara dengan agama Islam, sehingga Malaysia tidak dapat dinamakan negara sekuler. Konsekuensi lebih jauh, ajaran Islam dan hukum Islam dianut dan harus dilaksanakan di Federasi Malaysia

Dalam konstitusi Malaysia, prinsip perlindungan hak konstitusional dalam beragama menempati posisi yang sangat penting, universal dan sekaligus menegaskan Malaysia berkarakteristik sebagai negara hukum, namun demikian dalam praktik kehidupan sehari-hari, masih banyak hal-hal yang perlu disesuaikan dengan prinsip negara hukum. $^{26}$ Misalnya di lapangan kerja atau pekerjaan masih banyak terjadi pelanggaran terhadap kebebasan menjalankan agama, persoalan larangan majikan dan agen tenaga kerja atas kebebasan pekerja rumah tangga Muslim untuk berpuasa, sholat dan menghindari babi dan anjing sehubungan dengan keyakinan agama mereka merupakan pelecehan dan pelanggaran atas kemerdekaan beragama sebagaimana dilindungi dalam deklarasi hak asasi universal. (Lihat Pasal 18

Justice, Insaf, Vol.XXXV, No.1, Kuala Lumpur: The Journal of The Malayan Bar, The Bar Council,hlm.145.

${ }^{26}$ Muhammad Tahir Azhary,Loc.Cit, 217.
UDHR menetapkan, hak untuk bebas berpikir, berkehendak dan beragama. Dan kebebasan, baik sendiri atau bersama orang lain di masyarakat dan di tempat umum ataupun di rumah, untuk mewujudkan rasa keagamaannya dalam pengajaran, praktik, peribadatan dan ketaatan).

Meskipun dalam Konstitusi Malaysia secara jelas Islam merupakan agama resmi negara, tetapi praktik-praktik pelarangan dan tekanan untuk menjalankan kewajiban agama di tempat kerja masih menjadi hambatan yang sangat serius. ${ }^{27}$

Mengenai persoalan apakah Malaysia termasuk negara sekuler atau teokrasi , Shad Saleem Faruqi, menyatakan: ${ }^{28}$

"On the issue of an Islamic or secular state, it can be stated categorically that the Malaysian legal system is neither fully secular nor fully theocratic. It is hybrid. It permits legal pluralism. It avoids the extremes of American style secularism or Saudi, Iranian and Taliban type of religious control of all aspects of life. It mirrors the rich diversity and pluralism of its population".

(Tentang persoalan apakah Malaysia sebagai negara Islam atau sekuler, itu

27 Abdul Rasyid Saliman, 2018, Politik UndangUndang Perburuhan dan Model Perlindungan UndangUdang Integratif bagi Buruh Migran Indonesia di Malaysia, Artikel, dalam Peundangan Buruh malaysiaIndonesia dan Cabaran ASEAN, Bangi-Selangor DE: UKM Cetak Sdn.Bhd, hlm.140.Biasanya persoalan pelanggaran hubungan buruh dan majikan dalam pelaksanaan masalah agama dapat berawal dari penandatangan sampai pelaksanaan isi Kontrak perkhidmatan itu sendiri, lihat dalam Kamal Halili Hassan, 2015, Cabaran Peundangan dalam Hubungan Majikan dan Pekerja, Sektor Awam dan Swasta, BangiSelangor DE: UKM Cetak Sdn.Bhd, hlm. 18, dan dalamKamal Halili Hassan, 2015,Buruh Asing dan Migrasi Isu Perundangan, Bangi-Selangor DE: UKM Cetak Sdn.Bhd, hlm.72.

28 Shad Saleem Faruqi, 2004, Secularism or Theocracy - A Study of The Malaysian Constitution", UiTM Law Review, Vol.2, Shah Alam Selangor: Faculty of Law, UiTM, hlm.183. 
dapat dinyatakan dengan kategori bahwa sistem hukum Malaysia tidak secara penuh sekuler maupun teokrasi. Itu adalah sistem campuran atau cangkokan. Ini memperkenalkan hukum pluralis. Untuk menghindari gaya sekulerisme Amerika yang ekstrem atau Saudi, Iran dan Taliban dengan gaya kontrol keagamaan terhadap semua aspek kehidupan. Ini adalah cerminan dari keanekaragaman dan pluralisme yang kaya dari populasi nya).

Sehubungan dengan implementasi prinsip-prinsip nomokrasi Islam, maka di bawah ini akan ditelaah sejauh mana prinsipprinsip itu telah diakomodasikan atau dicantumkan dalam Konstitusi Malaysia, yaitu prinsip-prinsip musyawarah, keadilan, persamaan, kebebasan dasar (fundamental liberties), perlindungan hukum serta hak-hak kewarganegaraan lainnya (citizenship).

Tentang prinsip musyawarah dalam Konstitusi Malaysia tidak dijumpai secara tegas pengaturan mengenai prinsip ini. Tetapi dalam Pasal 38 ayat (1) Konstitusi Malaysia ada suatu lembaga konstitusional yang dinamakan "Majelis Raja-raja" (Conferences of Rulers) yang mempunyai wewenang antara lain memilih " Yang Dipertuan Agong" dan "Deputy Supreme Head of The Federation".

Dalam melaksanakan tugasnya Majelis Raja-raja tidak mengabaikan prinsip musyawarah sebagaimana diperintahkan oleh Al-Qur'an, mengingat Federasi Malaysia secara konstitusional telah dengan tegas menyatakan bahwa agama Islam adalah agama resmi negara tersebut. ${ }^{29}$

Di dalam praktik di Malaysia prinsip musyawarah itu diterapkan pula pada lembaga "Parlimen" sebagai Badan perundangundangan bagi Persekutuan Malaysia. Parlimen terdiri dari Yang Dipertuan Agong

29 Mohammad Agus Yusoff, 2006, Malaysian Federalism, Conflict or Consensus, Bangi: Universiti Kebangsaan Malaysia,hlm.20. dan dua Majelis Parlimen yaitu Dewan Negara dan Dewan Rakyat. Dewan Negara terdiri dari para anggota, 2 (dua) orang "ahli" yang dipilih oleh tiap-tiap Dewan Negeri, 2 (dua) orang "ahli" yang dipilih bagi tiap-tiap persekutuan dan 40 (empat puluh) orang "ahli". Mereka dilantik oleh yang Dipertuan Agong yang memiliki kriteria sebagai orang yang berjasa kepada rakyat atau dalam suatu profesi, misalnya perdagangan, pertanian, kebudayaan dan lain-lain.

Tentang "Pentadbiran Agama Islam" di Malaysia ada sejumlah peraturan misalnya sejak tahun 1959 sampai tahun 1983. Dalam hubungan dengan pelaksanaan prinsip musyawarah sebagai suatu prinsip nomokrasi Islam, maka prinsip ini dilaksanakan dalam praktik pada Majelis Agama Islam, sebagai badan perundangan yang diberi fungsi untuk membuat peraturan yang berhubungan dengan "pentadbiran" pengaturan tentang pengelolaan zakat, wakaf dan baitul maal. ${ }^{30}$

\section{Simpulan dan Saran}

\section{Simpulan}

Di Indonesia, meskipun tidak ada pengakuan secara tegas bahwa Islam adalah agama negara, tetapi ada pengakuan secara jelas agama Islam baik di dalam Alinea Ketiga dan Alinea Keempat Pembukaan UUD 1945 maupun di dalam Pasal 29 Batang Tubuh UUD 1945 sebagai agama negara. Di Indonesia, dalam praktik pengakuan hak beragama dapat di lihat dalam pembuatan beberapa peraturan perundang-undangan seperti UU Haji, UU Zakat, UU Perbankan Syariah, UU Perkawinan, UU Peradilan Agama, Qanun-Qanun di Aceh dan PerdaPerda Syariah yang berlaku di beberapa Provinsi dan Kabupaten/Kota di Indonesia.

Dalam Konstitusi Malaysia, prinsip perlindungan hak konstitusional dalam

\footnotetext{
${ }^{30}$ Ahmad Mohammad Ibrahim,1985, Sistem UndangUndang di Malaysia, Kuala Lumpur: Kementerian Pelajaran Malaysia, hlm.163.
} 
beragama menempati posisi yang sangat penting, universal dan sekaligus menegaskan Malaysia berkarakteristik sebagai negara hukum, namun demikian dalam praktik kehidupan sehari-hari, masih banyak hal-hal yang perlu disesuaikan dengan prinsip negara hukum. Dalam lapangan kerja atau pekerjaan masih banyak terjadi pelanggaran terhadap kebebasan menjalankan agama, persoalan larangan majikan dan agen tenaga kerja atas kebebasan pekerja rumah tangga Muslim untuk berpuasa, sholat dan menghindari babi dan anjing sehubungan dengan keyakinan agama mereka merupakan pelecehan dan pelanggaran atas kemerdekaan beragama sebagaimana dilindungi dalam deklarasi hak asasi universal.

Meskipun dalam Konstitusi Malaysia secara jelas Islam merupakan agama resmi negara, tetapi praktik-praktik pelarangan dan tekanan untuk menjalankan kewajiban agama di tempat kerja masih menjadi hambatan yang sangat serius.

\section{Saran}

Masalah perlindungan dan pengakuan hak beragama di Indonesia, walaupun agama Islam belum diakui dalam UUD 945 sebagai agama resmi negara, tetapi pengaturan dan pengakuan hak beragama secara materil diakui dalam beberapa produk perundangundangan bidang keagamaan. Oleh karena itu, bagi pemerintah Indonesia saat ini adalah perlu memperkuat pemahaman hak dan kewajiban sebagai warga negara dan penguatan lebih lanjut paham-paham kebangsaan dari perkembangan pemikiran baru ideologi agama yang sering dijadikan alat perjuangan oleh kelompok intoleransi.

Bagi pemerintah Malaysia, meskipun agama Islam secara formal diakui dalam konstitusi sebagai agama resmi negara, tetapi dalam tataran pelaksanaan masih banyak hambatan dalam pelaksanaannya. Oleh karena itu pemerintah Malaysia perlu memperkuat kesetaraan hak bagi setiap warga negara, tidak hanya warga negara yang beragama Islam saja, tetapi juga untuk warga negara pemeluk agama lainnya.

\section{DAFTAR PUSTAKA}

\section{Buku}

Abdul Rasyid Saliman, 2018, Politik UndangUndang Perburuhan dan Model Perlindungan Undang-Udang Integratif bagi Buruh Migran Indonesia di Malaysia, Artikel, dalam Perundangan Buruh Malaysia-Indonesia dan Cabaran ASEAN, Bangi-Selangor DE: UKM Cetak Sdn.Bhd.

Austin Sarat dan Thomas R. Kearns, 2000, Legal Rights, Michigan: The University of Michigam Press.

Adriaan Bedner, 2001, Administrative Courts in Indonesia, A Socio-Legal Study, The Hague-Netherland: Kluwer Law International.

Ahmad Mohammad Ibrahim, 1985, Sistem Undang-Undang di Malaysia, Kuala

Lumpur: Kementerian Pelajaran Malaysia.

Ade Maman Suherman, 2004, Pengantar Perbandingan Sistem Hukum, Jakarta: PT Raja Grafindo Persada.

Anwarul Yaqin, 2007, Legal Research and Writing, Selangor DE: Lexis Nexis Malaysia Sdn.Bhd.

Albert Van Dicey, 1952, Introduction to the Study of the Law of the Constitution, London: McMillan and Co., Limited St.Martin's Street, Terjemahan 2007 oleh Nurhadi, Bandung: Nusamedia.Internasional, Vol. 3, No. 3, Jakarta: LPHI-FH-Universitas Indonesia.

Charles Hector, 2006, Migrants and Rights in Malaysia more Important than

Rights is the Access to Justice, Insaf, Vol.XXXV, No.1,

Kuala Lumpur: The Journal of The Malayan Bar, The Bar Council. 
Fokky Fuad Wasitaatmadja, 2017, Filsafat Hukum, Akar Religiositas Hukum, Jakarta: Prenadamedia Group.

Ian Shapiro, 2006, Evolusi Hak dalam Teori Liberal, Jakarta: Freedom Institute dan Yayasan Obor Indonesia.

I Made Pasek Diantha, 2016, Metodologi Penelitian Hukum Normatif, Jakarta: Prenadamedia Group.

Johan S. Sabarudin, 2006, ConstitutionalismConcept and Application in the

Federal and State Goverments of Malaysia, Jurnal of Malaysian and Comparative Law, Vol.3, Kuala Lumpur: Faculty of Law, University of Malaya.

Johnny Ibrahim, 2006, Teori dan Metodologi Penelitian Hukum Normatif, Malang: Bayumedia Publishing.

Jonaedi Efendi dan Johnny Ibrahim, 2018, Metode Penelitian Hukum, Normatif dan Empiris, Jakarta Prenadamedia Group.

Kamal Halili Hassan, 1990, Penulis dan Undang-Undang, Selangor DE: Dewan Bahasa dan Pustaka.

2015,Cabaran Peundangan dalam Hubungan Majikan dan Pekerja, Sektor Awam dan Swasta, Bangi-Selangor DE: UKM Cetak Sdn.Bhd. 2015,Buruh Asing dan Migrasi Isu Perundangan, BangiSelangor DE: UKM Cetak Sdn.Bhd.

Lili Rasjidi dan Liza Sonia Rasjidi, 2005, Pengantar Metode Penelitian dan

Penulisan Karya Ilmiah Hukum, Bandung: FH-UNPAD.

Mohammad Agus Yusoff, 2006, Malaysian Federalism, Conflict or Consensus, Bangi: Universiti Kebangsaan Malaysia.
Muhammad Tahir Azhary, 2004, Negara Hukum, Suatu Studi tentang Prinsip-

Prinsipnya Dilihat dari Segi Hukum Islam, Implementasinya pada Periode Negara Madinah dan Masa Kini, Jakarta: Prenada Media.

Munir Fuady, 2014, Teori-Teori Besar dalam Hukum, Jakarta: Prenadamedia Group.

Neil Maccormick, 1986, Legal Right and Social Democracy, Oxford: Clarendon Pres.

Shad Saleem Faruqi, 2004, Secularism or Theocracy - A Study of The Malaysian Constitution", UiTM Law Review, Vol.2, Shah Alam Selangor: Faculty of Law, UiTM.

\section{Peraturan Perundang-Undangan}

Undang-Undang Dasar RI Tahun 1945

Konstitusi Malaysia 1957 ( 1957 Malaysia Constituition )

Akta Pekerjaan Malaysia 1955 (1955 Employment Act of Malaysia)

Akta Pampasan Malaysia 1952 ( 1952 Workmen's Compensation Act of Malaysia)

Akta Keselamatan Dalam Negeri $1960(1960$ Internal Security Act)

Akta Imigresyen 1154 Malaysia 2002

Jurnal

Universal Declaration of Human Rights (UDHR)

Convention on the Elimination of All Forms of Discrimination againts Women (CEDAW)

Website

http://www.hrw.org.indonesian/reports. 